\title{
Relationship of temporomandibular disorders with selected systemic diseases
}

\section{Zaburzenia czynnościowe układu stomatognatycznego na tle wybranych chorób ogólnoustrojowych}

\author{
Olaf Gruca1, Monika Tysiąc-Miśta ${ }^{2}$, Aleksandra Czelakowska ${ }^{1}$, Patrycja \\ Lanowy $^{3}$, Miłosz Bichalski ${ }^{3}$, Jakub Dzindzio ${ }^{3}$, Jacek Kasperski ${ }^{1}$, Marlena Biel ${ }^{1}$ \\ ${ }^{1}$ Zaklad Protetyki Stomatologicznej Katedry Protetyki i Materiałoznawstwa Stomatologicznego, \\ Śląski Uniwersytet Medyczny w Katowicach \\ Department of Prosthodontics, Chair of Prosthetics and Dental Materials Sciences, \\ Medical University of Silesia in Katowice \\ Head: prof. dr hab. n. med. Jacek Kasperski
}

${ }^{2}$ Zakład Materiałoznawstwa Stomatologicznego Katedry Protetyki i Materiałoznawstwa Stomatologicznego, Śląski Uniwersytet Medyczny w Katowicach

Head: dr n. med. Magdalena Wyszyńska-Chtap
${ }^{3}$ Studenckie Koło Naukowe Zakładu Protetyki Stomatologicznej Katedry Protetyki i Materiałoznawstwa Stomatologicznego, Śląski Uniwersytet Medyczny w Katowicach
Students' Research Group at the Department of Prosthodontics, Chair of Prosthetics and Dental Materials
Sciences, Medical University of Silesia in Katowice

KEY WORDS:

temporomandibular disorders, rheumatic diseases, stress, headache, migraine

\section{Summary}

Temporomandibular disorders (TMD) it is a term used for a set of disorders, whose symptoms include, among others, face and neck muscle pain, temporomandibular joint (TMJ) pain, acoustic symptoms in TMJ, and derange pattern and range of movement.. At some point in their life, even $50-75 \%$ of the population may be afflicted by these disorders. . The etiology of TMD is not fully known. TMD occurrence is determined by factors such as congenital, emotional or external factors. The purpose of this article is to explore the information contained in scientific literature on TMD as a medical condition that occurs in the course of many diseases and may accompany some systemic disorders. It has to be remembered that this disorder may not function as a separate

\section{HASŁA INDEKSOWE:}

zaburzenia czynnościowe układu stomatognatyczngo, choroby reumatyczne, stres, ból głowy, migrena

\section{Streszczenie}

Schorzenia skroniowo-żuchwowe (ang. temporomandibular disorders, TMD) sq zespołem zaburzeń charakteryzujacych się między innymi bólem mięśni w obrębie twarzy, głowy i szyi, bólami stawu skroniowo-żuchwowego (ssż), objawami akustycznymi czy też zaburzeniami toru oraz zakresu ruchów żuchwy. Zaburzenia $w$ obrębie narzadu żucia moga w pewnym okresie życia dotyczyć nawet 50-75\% populacji. Etiologia TMD nie jest do końca znana. Występowanie schorzeń jest zdeterminowane występowaniem wielu czynników, m.in. czynnikami wrodzonymi, zewnętrznymi, emocjami. Celem tego pogladowego artykutu jest zglębienie informacji o TMD, jako schorzeniu pojawiajacym sie $w$ przebiegu wielu chorób i zaburzeń stanu organizmu. Należy 
disease entity but be a symptom of other conditions. The article deals with, inter alia, TMD coexistence with headache, especially of migraine origin, correlation between rheumatic diseases or stress, and functional disorders of the temporomandibular joints. Its main objective is to to broaden the knowledge, suggest treatment methods in such cases and promote a holistic approach to treatment.

\section{Introduction}

Temporomandibular disorders (TMD) constitute a spectrum of disorders of diverse etiology and symptoms. These disorders affect the temporomandibular joint, masticatory muscles, or both. When only are discussed). ${ }^{1,2}$ TMD these are common - research indicates that at some point in life these disorders may affect even $50-75 \%$ of the population. ${ }^{3}$ Clinical symptoms of temporomandibular joints disorder (TMJ) can occur in even 5\% to $33 \%$ of the population. ${ }^{4}$ The peak in the occurrence of TMD appears between 20 and 40 years of age. These disorders are 2-3times more frequently affect women than men, moreover the range of symptoms in women is clearly wider than in the opposite sex. ${ }^{5-7}$

The most common symptoms of temporomandibular joints disorders include pain, independent or during mandibular movement and acustic signs, derange pattern and range of mandibular movement, problems with chewing foodthe ${ }^{8}$ However, the most common reason why patients seek help is pain of the masticatory muscles, headaches and pain in the neck. ${ }^{6}$ Other comorbid symptoms include otalgia and tinnitus.

The aetiology of TMD is complex and not fully understood, the occurrence of diseases pamiętać, że schorzenie to nie musi funkcjonować jako samodzielna jednostka chorobowa, ale także jako objaw innych zaburzeń. W artykule opisano wspótistnienie TMD oraz bólów głowy, szczególnie pochodzenia migrenowego, korelację między chorobami reumatycznymi czy też stresem a zaburzeniami czynnościowymi stawów skroniowo-żuchwowych. Intencja autorów jest poszerzenie wiedzy czytajacego, zasugerowanie metod terapeutycznych oraz propagowanie holistycznego podejścia do leczenia TMD.

\section{Wprowadzenie}

Zaburzenia skroniowo-żuchwowe (ang. Temporomandibular Disorders - TMD) to spektrum zaburzeń o zróżnicowanej etiologii i symptomach. Schorzenia te obejmują zaburzenia występujące w stawach skroniowo-żuchwowych (ssż), mięśniach żucia, lub jednych i drugich jednocześnie. ${ }^{1,2}$ Schorzenia te są powszechne badania wskazują, że w pewnym okresie życia zaburzenia te mogą dotyczyć nawet $50-75 \%$ populacji. ${ }^{3}$ Kliniczne symptomy zaburzeń ze strony stawów skroniowo-żuchwowych mogą występować w zakresie nawet od 5\% do 33\% społeczeństwa. ${ }^{4}$ Szczyt występowania TMD ma miejsce między 20 a 40 rokiem życia. Zaburzenia te 2-3 razy częściej występują u kobiet niż u mężczyzn, ponadto rozpiętość objawów u kobiet jest wyraźnie szersza niż u płci przeciwnej. ${ }^{5-7}$ Do najczęstszych objawów schorzeń stawów skroniowo-żuchwowych zalicza się ból, samoistny lub podczas ruchów żuchwy, występowanie objawów akustycznych, zaburzenie toru oraz zakresu tych ruchów, problemy z żuciem pokarmów. ${ }^{8}$ Najczęstszą przyczyną, z powodu której pacjenci szukają pomocy, jest ból w obrębie mięśni żucia, twarzy, głowy oraz szyi. ${ }^{6}$ Inne współistniejące objawy to otalgia oraz szumy uszne.

Etiologia TMD jest złożona i nie do końca poznana, występowanie schorzeń jest 
is caused by the interaction between various factors - parafunctions, emotions, congenital, external and internal factors. ${ }^{7,9-11}$ Dysfunctions of this joint can be divided into general (including psychogenic factors) and local (joint and occlusion). ${ }^{12}$

The main cause of dysfunction of the temporomandibular joints is displacement of the disc. ${ }^{12}$ Iatrogenic factors predisposing to the occurrence of TMD include improperly performed restorations or fillings. ${ }^{12-14}$ Functional dysfunctions in this joint are caused by increased tension of the head and neck muscles (caused by increased emotional tension) and problems with occlusion due to tooth loss. ${ }^{15}$ The factors not directly related to the condition of the temporomandibular joints are: spinal defects and postures, sarcoidosis, hormonal disorders, gout, ankylosis or osteoarthritis. ${ }^{9,16}$

In the relevant literature on masticatory dysfunction, many complicated classifications can be found. ${ }^{9,14}$ In 1992, Dworkin and LeResche proposed a new classification based on system known as Research Diagnostic Criteria for Temporomandibular Disorders, RDC/TMD, the purpose of which was to standardize the criteria for research, based on the knowledge of this pathology. ${ }^{17}$

Correct diagnosis of TMD is necessary for introducing an effective treatment. The type of temporomandibular disorder can be determined by the properly targeted medical history interview and the clinical examination. Anamnesis may be supplemented with the McGill-Malzack questionnaire. ${ }^{12,18-20}$ The physical examination should include occlusal analysis, examination of jaw mobility, examination of masticatory muscles and TMJ. ${ }^{19,21}$ In the diagnostic process, some accessorytestsareusefultoconfirm the diagnosis or in cases whch are difficult to diagnose. They include imaging diagnostics, arthroscopy, EMG, scintigraphy, ultrasound. ${ }^{9,12}$ Diagnostic spowodowane oddziaływaniem między różnymi czynnikami (np. czynnikami wrodzonymi, parafunkcjami, emocjami, czynnikami zewnętrznymi i wewnętrznymi). ${ }^{7,9-11}$ Główną przyczyną dysfunkcji stawów skroniowo-żuchwowych jest przemieszczenie krążka stawowego. ${ }^{12}$ Jatrogenne czynniki predysponujące do wystąpienia TMD to między innymi nieprawidłowo wykonane uzupełnienia protetyczne czy wypełnienia. ${ }^{12-14}$ Czynnościowe zaburzenia ssż mogą być spowodowane przez nadmierne napięcie mięśni głowy i szyi (m.in. na skutek wzrostu napięcia emocjonalnego), czy też zaburzenia zwarcia związane z utratą zębów. ${ }^{15}$ Czynnikami niezwiązanymi bezpośrednio ze stanem stawów skroniowo-żuchwowych są: wady kręgosłupa i postawy, sarkoidoza, zaburzenia hormonalne, dna moczanowa, ankyloza czy zapalenie kości.9,16

W piśmiennictwie dotyczącym dysfunkcji narządu żucia można znaleźć wiele skomplikowanych klasyfikacji. ${ }^{9,14}$ W 1992 roku Dworkin i LeResche zaproponowali nowy system klasyfikacji schorzeń znany jako diagnostyczne kryteria badawcze (ang. Reasearch Diagnostic Criteria for Temporomandibular Disorders, RDC/TMD). ${ }^{17}$ Poprawne zdiagnozowanie TMD jest niezbędne do wdrożenia skutecznego leczenia. Rodzaj zaburzeń określa się dzięki odpowiednio ukierunkowanemu wywiadowi oraz badaniu klinicznemu. Badanie podmiotowe można uzupełnić o kwestionariusz McGilla-Malzacka. ${ }^{12,18-20}$ Badanie przedmiotowe powinno zawierać analizę zwarcia, określenie ruchomości żuchwy, badanie mięśni żucia i ssż. ${ }^{19,21} \mathrm{~W}$ diagnostyce wykorzystuje się również badania dodatkowe, które są przydatne do potwierdzenia diagnozy lub w przypadkach trudnych diagnostycznie. Zalicza się do nich m.in. diagnostykę obrazową, artroskopię, EMG, scyntygrafię. ${ }^{9,12}$ Do obrazowych metod diagnostycznych należą badania radiologiczne (zdjęcie ortopantomograficzne z programem dla ssż, tomografia komputerowa $)^{9,10,19}$ 
imaging methods include radiological examinations (orthopantomographic picture with a program for TMJ, computed tomography). ${ }^{9,10,19}$ Magnetic resonance imaging provides an insight into hard and soft tissues. ${ }^{10,22}$ Ultrasounds show the soft tissues of TMJ that are imperceptible on conventional X-ray imaging; additionally it is also possible to observe the articular disc in actual time, during movements of the mandible and the activity (contraction) of the masticatory muscles. ${ }^{22}$ EMG allows us to evaluate the differences in masticatory muscle tension on both sides, which allows us to evaluate symmetry of work of these muscles. Scintigraphy is used in the diagnosis of bone abnormalities. Invasive method of evaluation of the TMJ condition is arthroscopy. ${ }^{10,21,23} \mathrm{In}$ the diagnosis, the RDC/TMD test is useful it consists of an interview, recommendations for conducting a physical examination and contains appropriate diagnostic criteria based on the biopsychosocial model. ${ }^{14,18}$

To treat diagnosed TMJ disorders properly, it is necessary to provide complex and interdisciplinary therapy. Treatment should be adapted to the cause of the diagnosed lesions. ${ }^{14,24}$ The gold standard for treating TMJ disorders is splint therapy. It is used in most cases of TMD and the type of splint should be chosen for the type of the disorder, that is why correct diagnosis of dysfunction is so important. In TMD treatment a stabilizing splint is used, which is also called the relaxation splint, covering the upper or lower dental arch, which has got flat occlusal surface with canine guidance. This splint is effective in reducing muscular pain, moreover it is safe in use since it does not cause irreversible changes. In the treatment of disorders in the temporomandibular joints, short-term reflex splints are also used and repositioning splints. ${ }^{24,26}$ NSAIDs and steroids are used to treat pain. An important role in the treatment rezonans magnetyczny, który umożliwia wgląd do tkanek twardych jak i miękkich, ${ }^{10,12}$ a także USG, które obrazuje tkanki miękkie ssż niewidoczne na konwencjonalnych zdjęciach RTG. Dodatkowo możliwa jest także obserwacja krążka stawowego w czasie rzeczywistym, podczas ruchów żuchwy oraz praca mięśni żucia. ${ }^{22}$ EMG umożliwia ocenę różnic napięcia mięśni żucia, natomiast scyntygrafia jest używana $\mathrm{w}$ diagnostyce nieprawidłowości kostnych. Inwazyjną metodą oceny stawu jest artroskopia. ${ }^{10,21,23} \mathrm{~W}$ diagnostyce przydatny jest kwestionariusz RDC/TMD oparty na modelu biopsychosocjalnym schorzeń - składa się on z wywiadu, zaleceń odnośnie przeprowadzenia badania przedmiotowego oraz zawiera odpowiednie testy w celu oceny również stanu psycho-emocjonalnego pacjenta. ${ }^{14,18}$

Aby skutecznie leczyć zdiagnozowane zaburzenia ssż, do terapii należy podejść kompleksowo i interdyscyplinarnie. Leczenie powinno być dostosowane do przyczyn zdiagnozowanych zmian. ${ }^{14,24}$ Złotym standardem w leczeniu zmian ssż jest szynoterapia, mająca zastosowanie w większości przypadków TMD. Rodzaj szyny powinien być dobrany do typu zaburzeń - dlatego tak ważna jest poprawna diagnostyka dysfunkcji. W TMD stosowana jest szyna stabilizacyjna, która jest również nazywana szyną relaksacyjną, pokrywa ona górny lub dolny łuk zębowy, posiada płaską powierzchnię zwarciową z prowadzeniem kłowym. Szyna ta jest skuteczna w redukcji bólów o przyczynie mięśniowej, ponadto jest szyną bezpieczną, gdyż nie powoduje nieodwracalnych zmian w okluzji. W leczeniu zaburzeń w stawach skroniowo-żuchwowych zastosowanie mają także szyny odruchowe - stosowane krótkoczasowo oraz szyny repozycyjne. ${ }^{25,26} \mathrm{~W}$ leczeniu bólu zalecane są niesteroidowe leki przeciwzapalne (NLPZ) oraz sterydy. Istotną rolę w leczeniu niektórych przypadków odgrywa redukcja czynników stresujących, nauka metod relaksacyjnych czy psychoterapia. Do inwazyjnych 
of some cases is the reduction of stressors, learning relaxation methods or psychotherapy. The invasive methods of TMD treatment include surgery and prosthetic reconstruction - Complementing the main treatment are physical methods, including electrotherapy, magnetotherapy, phototherapy, TENS therapy or ultrasound therapy. ${ }^{23,25}$

\section{TMD and stress}

Stress is a psychological factor that may cause grinding of teeth, gnashing and clenching jaws and in consequence pain. The diagnosis, control and treatment of patients with temporomandibular disorder is one of the most difficult problems, considering the fact that temporomandibular joints disorders have varied character and symptoms. ${ }^{27-29}$ Studies have shown a close relationship between pain and psychosocial disorders (stress, depression, chronic fatigue, sleep disorders) in patients with TMD. ${ }^{28-32}$ The essential cause of stress may be anxiety - studies have shown that people with TMD have got a very high level of anxiety, and that the pain in the face and head that occurs in these patients is caused by stress. ${ }^{33,34}$ Manfredini et al., carried out a study using stress measurement questionnaires and disclosed that compared to other disorders of oral conditions, stress was significantly higher in the TMD patients. ${ }^{35}$ Madani et al. found that stress played a significant role in the aetiology of TMD, and determined that risk factors such as premature contact, grinding and clenching, and injuries of joints are less important than stress in TMD formation. ${ }^{36}$ In conclusion, stress is an important factor affecting TMD. ${ }^{27-32,35,36}$

In order to diagnose whether stress is the cause of TMD symptoms, stress questionnaires are used. Other possible causes, muscle tension caused by nerve causes, degeneration, genetic factors, etc., should be eliminated. The next step to get rid of TMD symptoms caused metod leczenia TMD należą zabiegi operacyjne oraz rekonstrukcje protetyczne. Uzupełnieniem leczenia głównego są metody fizykalne, między innymi: elektroterapia, magnetoterapia, fototerapia, terapia TENS czy terapia ultradźwiękami. $^{24,25}$

\section{TMD a stres}

Stres należy do czynników psychologicznych, który może odgrywać istotną rolę w postawaniu tego typu zaburzeń. Wraz ze stresem może pojawić się zgrzytanie zębami, zaciskanie szczęk i w efekcie ból. Rozpoznanie, kontrola i leczenie pacjentów z zaburzeniami skroniowo-żuchwowymi są jednym z najtrudniejszych problemów, biorąc pod uwagę fakt, że zaburzenia stawów skroniowo-żuchwowych mają różny charakter i objawy. ${ }^{27-29}$ Badania wykazały istnienie bliskiego związku między bólem a zaburzeniami psychospołecznymi (stres, depresja, przewlekłe zmęczenie, zaburzenia snu) u pacjentów z TMD. ${ }^{28-32}$ Istotną przyczyną stresu może być lęk - badania dowodzą, że osoby z TMD mają bardzo wysoki poziom lęku, a występujące u pacjentów bóle twarzy i głowy są spowodowane stresem..$^{33,34}$ Manfredini i wsp. przeprowadzili badanie z wykorzystaniem kwestionariuszy pomiaru stresu i wykazali, że w porównaniu do innych różnych zaburzeń w jamie ustnej, stres był istotnie wyższy w grupie pacjentów z TMD. ${ }^{35}$ Natomiast Madani i wsp. w swoim badaniu stwierdzili, że stres odgrywał znaczną rolę w etiologii TMD oraz ustalili, że czynniki ryzyka, takie jak przedwczesny kontakt, zaciskanie oraz zgrzytanie zębów, jak i urazy stawów mają mniejsze znaczenie w powstawaniu TMD. ${ }^{36}$ Wnioskując, stres jest istotnym czynnikiem mającym wpływ na TMD. ${ }^{27-32,35,36}$

W celu zdiagnozowania czy stres jest powodem objawów TMD stosuje się kwestionariusze stresu, najpierw należy jednak wykluczyć inne możliwe przyczyny, tj. napięcie mięśniowe spowodowane przyczynami 
Ta b le 1. Active exercise used in stress reduction

\begin{tabular}{|l|l|}
\hline \multicolumn{1}{|c|}{ Active excercises } & \multicolumn{1}{|c|}{ Method } \\
\hline Physical activity & $\begin{array}{l}\text { running, swimming, gym, gymnastics - improves mood by increasing the release of } \\
\text { endorphins }\end{array}$ \\
\hline $\begin{array}{l}\text { Progressive } \\
\text { Jacobson's relaxation }\end{array}$ & $\begin{array}{l}\text { consists in alternating tensioning and loosening of the subsequent parts of the } \\
\text { muscles of your body, starting from the feet and ending on the face, you can feel the } \\
\text { state of relaxation after the whole cycle }\end{array}$ \\
\hline Relaxing massage & touch soothes the senses and calms the mind \\
\hline Choreotherapy & $\begin{array}{l}\text { dance therapy - it is a body work to the rhythm of music, thanks to which we can } \\
\text { harmonize the body and calm our mind }\end{array}$ \\
\hline
\end{tabular}

Ta b le 2. Passive exercise used in stress reduction

\begin{tabular}{|l|l|}
\hline Passive excercises & \\
\hline $\begin{array}{l}\text { Relaxation through } \\
\text { the breath }\end{array}$ & $\begin{array}{l}\text { Method } \\
\text { indirectly calm our emotions }\end{array}$ \\
\hline Visualization & $\begin{array}{l}\text { you have to completely cut off from the stressful situation and imagine a pleasant } \\
\text { moment for us, e.g. image of relaxing on the beach }\end{array}$ \\
\hline Reframing & $\begin{array}{l}\text { very similar technique to the previous one, with the only difference that we only } \\
\text { change the context of a stressful situation, for positive, funny one. }\end{array}$ \\
\hline Aromatherapy & $\begin{array}{l}\text { high effectiveness is associated with the fact that the sense of smell is closely related } \\
\text { to the part of our brain that is responsible for emotions }\end{array}$ \\
\hline Music therapy & thanks to calmer music, we are able to calm down and look away \\
\hline Other methods & slow addition e.g. $1+1=2,2+1=3$, quiet counting/listing items around \\
\hline
\end{tabular}

by stress is to eliminate or reduce stressing situations. There are many effective ways to fight stress. We can divide them into two groups: active and passive (Table 1 and Table 2). ${ }^{37}$

In some cases, TMD symptoms may resolve without treatment. If the symptoms persist, different treatment options of can be recommended. Often treatment consists of combining several methods at the same time. The use of a relaxation splint, combined with physical treatments (laser, ultrasounds, magnetotherapy) and physiotherapy (massage, stretching, relaxation) gives satisfactory nerwowymi, zwyrodnienia, czynniki genetyczne. Następnym krokiem do pozbycia się objawów TMD wywołanych stresem jest eliminacja lub ograniczenie sytuacji stresowych. Jest wiele skutecznych sposobów na walkę ze stresem, dzieli się je na dwie grupy aktywne i pasywne (tab. 1, tab. 2). ${ }^{37}$

W niektórych przypadkach objawy TMD mogą ustąpić bez leczenia. Jeśli objawy utrzymują się, można zlecić różne opcje leczenia, często stosuje się łącznie kilka metod w tym samym czasie. Zastosowanie szyny relaksacyjnej w połączeniu z zabiegami fizykalnymi (laser, ultradźwięki, magnetoterapia), jak i fizjoterapią 
results. Analgesics are administered and antiinflammatories to relieve pain in the TMJ and its vicinity. Consultation with a psychologist also brings beneficial effects. ${ }^{38}$ In addition, cold and warm compresses or alternative medicine (acupuncture, biofeedback) can be tried. For the reduction of muscle tone, we can use muscle relaxants, while in more severe cases of TMD symptoms surgical procedures are used. ${ }^{39}$

\section{TMD and rheumatic diseases}

Rheumatic diseases are a group of diseases, most of which have got autoimmune and inflammatory basis. ${ }^{40}$ Ailments from motor organs affect $30-40 \%$ of the European population, and neglect in rapid diagnosis and treatment may lead to a disability. ${ }^{41}$ Research carried out by Lordache et al., whose aim was to assessthe prevalence of TMJ disorders in patients suffering from various rheumatic diseases, proved that the pathology in the area of this joint is higher in all the examined groups (among others, patients with juvenile idiopathic arthritis, psoriatic arthritis, rheumatoid arthritis and osteoarthritis) regardless of whether they are inflammatory or degenerative rheumatic diseases. ${ }^{42}$

\section{Rheumatoid arthritis (RA)}

$\mathrm{RA}$ is an aggressive autoimmune disease of the joints that causes their deformation and impairment of function. ${ }^{43}$ Two serological forms are distinguished depending on the presence or absence of serum autoantibodies - a positive and a negative form, respectively. ${ }^{40}$ This disorder is most common in women and the elderly. In $50 \%$ of cases, the risk of RA is attributed to genetic factors, and the estimated number of adults affected by rheumatoid arthritis in industrialized countries is $0.5-1.0 \% .{ }^{44}$ When it comes to people who do not have clinical (masaż, rozciąganie, relaksacja) przynoszą zadowalające efekty. Do złagodzenia bólu w ssż i jego okolicy stosuje się leki przeciwbólowe i przeciwzapalne, korzystne efekty przynosi również kontakt z psychologiem. ${ }^{38}$ Dodatkowo można stosować zimne i ciepłe okłady lub medycynę alternatywną (akupunktura, biofeedback). Dla zmniejszenia napięcia mięśniowego wskazane są leki relaksujące mięśnie, natomiast w cięższych przypadkach objawów TMD stosuje się zabiegi chirurgiczne. ${ }^{39}$

\section{TMD a choroby reumatyczne}

Choroby reumatyczne to zespół chorób W większości o podłożu autoimmunizacyjnym i zapalnym..$^{40}$ Dolegliwości ze strony narządu ruchu dotyczą 30-40\% populacji europejskiej, a zaniedbania w szybkiej diagnostyce i leczeniu mogą doprowadzić do niepełnosprawności. ${ }^{41}$ Badania Lordache i wsp. odnośnie oceny częstości zaburzeń ssż u pacjentów cierpiących na różne choroby reumatyczne udowodniły, że patologia w obrębie tych stawów wykazuje większą częstość występowania we wszystkich badanych grupach (m.in. pacjenci z młodzieńczym idiopatycznym zapaleniem stawów, łuszczycowym zapaleniem stawów, reumatoidalnym zapaleniem stawów i chorobą zwyrodnieniową stawów), niezależnie od zapalnych lub zwyrodnieniowych chorób reumatycznych. ${ }^{42}$

Reumatoidalne zapalenie stawów - RZS (ang. rheumatoid arthritis $-R A$ )

RZS jest agresywną chorobą autoimmunologiczną stawów, która powoduje ich deformację oraz upośledzenie czynności. ${ }^{43}$ Wyróżnia się dwie postacie serologiczne zależnie od obecności lub nieobecności w surowicy autoprzeciwciał - odpowiednio formę dodatnią oraz ujemną. ${ }^{40}$ Zaburzenie najczęściej występuje u kobiet i osób starszych. W 50\% ryzyko wystąpienia RZS przypisuje się czynnikom genetycznym, a szacowana liczba osób dorosłych dotkniętych reumatoidalnym zapaleniem 
symptoms of RA affecting the TMJ - the structure of the joint may be destroyed, which is only visible with imaging methods. Therefore, early diagnosis and treatment implementation are very important. ${ }^{45,46}$ In $75 \%$ of cases of TMJ disorders in RA ailments include pain in the craniofacial region, as well as pain in the joints, muscles or both. ${ }^{45}$ In later stages there may occur: stiffness of joints, limitation of jaw movements and muscle spasms, but it is the pain which is considered (in $66 \%$ of patients) as the most critical problem. ${ }^{47,48}$ When we need to diagnose if RA starts to affect the TMJ, magnetic resonance imaging (MRI) is used, which is obligatory to assess soft tissue abnormalities. ${ }^{49}$ The MRI image will reveal bone condition, soft tissues ( bone marrow pathology, swelling of lymph nodes in parotid salivary glands) and abnormal position of the articular disc (in $95.2 \%$ of cases), abnormal articular disc morphology (in $83.3 \%$ ) or articular exudate (in $30.9 \%$ ). ${ }^{50}$ The frequency of displacement of the disc in people with RA does not significantly differ from patients not suffering from RA (only with $\mathrm{MD}$ ), but the mechanism of movement may be different. People with TMD have changes in the shape of the joint disc, while in patients with RA the condylar bone is resorbed, which disrupts the relationship between it and the joint disc. ${ }^{51}$ Another diagnostic method is cone-beam computed tomography (CBCT), which very precisely images hard tissues in the TMJ area, whose assessment is comparable to conventional radiographic and MRI scans, but it should be remembered that information obtained from CBCT is limited to the morphology of bone joint components, cortical bone integrity and subcortical destruction of bone. ${ }^{49}$

Treatment of patients with RA with coexisting TMD consists in improving the quality of life. In treatment protocol in this case we can distinguish patient education, pharmacological treatment, rehabilitation, and orthopedic treatment. ${ }^{40}$ stawów w krajach uprzemysłowionych wynosi 0,5-1,0\%. ${ }^{44} \mathrm{~W}$ przypadku osób z RZS, u których nie stwierdza się objawów klinicznych w ssż może dochodzić do zniszczenia struktury stawu, uwidacznianych dopiero w metodach obrazowych, dlatego duże znaczenie ma wczesna diagnostyka i wdrożenie leczenia. ${ }^{45,46}$ Do dolegliwości ze strony ssż w 75\% należą bóle w okolicy części twarzowej czaszki, w tym bóle stawów i/lub mięśni. ${ }^{45} \mathrm{~W}$ późniejszych etapach mogą dołączyć się: sztywność stawów, ograniczenie ruchów żuchwy i skurcze mięśni, jednak ból jest uznawany (u 66\% pacjentów) za najważniejszy problem. ${ }^{47,48} \mathrm{~W}$ diagnozowaniu wykorzystywany jest rezonans magnetyczny (MRI), w obrazie widoczne są zmiany w strukturach kości i tkankach miękkich ${ }^{49}$ (nieprawidłowości szpiku kostnego żuchwy, obrzęk węzłów chłonnych w śliniankach przyusznych) oraz nieprawidłowa pozycja krążka (w 95,2\% przypadków), nieprawidłowa morfologia krążka (w 83,3\%) czy wysięk stawowy (w 0,9\%). ${ }^{50}$ Częstość przemieszczenia krążka u osób z RZS nie jest znacząco różna od pacjentów, którzy nie chorują na RZS (cierpiących wyłącznie na TMD), lecz mechanizm przemieszczania się może być odmienny. Osoby z TMD wykazują zmiany kształtu krążka stawowego, podczas gdy u pacjentów z RZS zostaje zresorbowana kość wyrostka kłykciowego, a przez to może dojść do zaburzenia relacji między nim a krążkiem stawowym. ${ }^{51}$ Inną metodą diagnostyczną jest tomografia stożkowa (CBCT), która wykazuje się bardzo dokładnym obrazowaniem tkanek twardych w obrębie TMJ. Należy jednak pamiętać, że informacje uzyskane z CBCT ograniczają się do morfologii składników stawu kostnego, integralności kości korowej, oraz podkorowego niszczenia produkcji kości. ${ }^{49}$

Leczenie pacjentów z RZS z współwystępującym TMD polega na poprawie jakości życia, edukacji pacjentów, leczeniu farmakologicznym, rehabilitacji oraz leczeniu ortopedycznym. ${ }^{40}$ 


\section{Osteoarthritis (OA)}

$\mathrm{OA}$ is the most common inflammatory disease of the joints. The risk of symptomatic knee osteoarthritis during the whole life is $44.7 \% .^{52}$ Its progress depends on the action of microinjuries and biological factors. The prognostic factors include age, obesity, female gender, genetic mutations, or job-related mechanical factors, extreme sports and past injuries. ${ }^{40} \mathrm{OA}$ in temporomandibular joint is characterized by cartilage degradation, subchondral bone remodeling and chronic inflammation in the synovial tissue. Clinical symptoms may include clinical problems with masticatory muscles, impairment of jaw movement and appearance of pain. ${ }^{53-56}$ The disease can be diagnosed on CBCT picture, typically revealing erosion of the condylar bone, flattening and osteophytes. ${ }^{57}$ Studies on the relationship between the presence of articular exudate and osteoarthritis in the jaw joint (diagnosed using MRI) along with the displacement of the disc with reduction (DDwR) showed that in most cases there was no evidence of articular exudate in people with inflammation of bones and joints in joints with this type of displacementlocation. ${ }^{58}$

The use of imaging is necessary because the clinical criteria alone are insufficient for the proper diagnosis of TMJ arthritis, furthermore there were weak correlations between the occurrence of bone lesions and clinical symptoms of TMJ-OA; in this case the use of CBCT provides a clear visualization of TMJ hard tissue. ${ }^{57,58}$ A study by Kothari et al., on pain profiling in patients with arthritic pain of TMJ and in patients with osteoarthritis showed that in the first group patients were less sensitive to warm, cold and tactile stimulation than in the second group. What is more, arthritic TMJ patients showed hypertension. ${ }^{60}$ Treatment of TMD in OA relies on alleviating pain, preventing the destruction of cartilage and subchondral bone, and restoring the function
Choroba zwyrodnieniowa stawów (ang. Osteoarthritis - OA)

OA jest najczęstszą chorobą o charakterze zapalnym stawów. Przykładowo ryzyko wystąpienia objawowego zwyrodnienia stawu kolanowego w ciągu całego życia wynosi 44,7\%.52 Jej rozwój jest zależny od działania mikrourazów i czynników biologicznych, a do czynników prognostycznych zalicza się, m.in. starszy wiek, otyłość, płeć żeńską, mutacje genetyczne, czy czynniki mechaniczne zależne od pracy zawodowej, uprawiania sportów ekstremalnych i urazów w przeszłości ${ }^{40}$ Zajęcie przez OA stawu skroniowo-żuchwowego charakteryzuje się degradacją chrząstki, podchrzęstną przebudową kości i przewlekłym stanem zapalnym w tkance maziowej. Do występujących symptomów można zaliczyć problemy kliniczne w mięśniach żucia, upośledzenie zakresu ruchu żuchwy oraz pojawiający się ból. ${ }^{53-56}$ Schorzenie można diagnozować za pomocą CBCT, w obrazie którego występuje zazwyczaj erozja kości kłykcia, spłaszczenie i osteofity. ${ }^{57}$ Badania dotyczące związku obecności wysięku stawowego u osób chorujących na zapalenie kości i stawów oraz ssż (diagnozowanych przy użyciu rezonansu magnetycznego) wraz z przemieszczeniem krążka stawowego bez zablokowania (PKBZ) wykazały, że W większości przypadków nie stwierdza się obecności wysięku stawowego. ${ }^{58}$

Zastosowanie obrazowania jest konieczne, ponieważ same kryteria kliniczne stanowią niewystarczające dane do prawidłowego rozpoznania zapalenia stawów sż, ponadto stwierdzono słabe zależności między występowaniem zmian kostnych a klinicznymi objawami ssż w OA, w tym przypadku zastosowanie CBCT zapewnia czytelną wizualizację twardych tkanek ssż. ${ }^{57,59}$ Badanie Kothari i wsp. odnośnie profilowania bólu u pacjentów z bólami stawowymi ssż i pacjentów z chorobą zwyrodnieniową stawów wykazały, że w przypadku pierwszej grupy, przy ocenie funkcji somatosensorycznej 
of joints. Currently, the most commonly used therapies (non-steroidal anti-inflammatory drugs, splint therapy with stabilizing splints, low-level lasers) are effective in preventing pain and other symptoms but they do not have a therapeutic effect on the pathological structure of the joint. The procedure for reversing TMJ damage in $\mathrm{OA}$ is currently unavailable. ${ }^{55}$ Positive results of treatment of temporomandibular joint degeneration with displacement of the joint disc are obtained by injection of hyaluronic acid (HA) into the upper or lower joint space, but injection of HA into the lower joint space results in better remodeling of the condyle. ${ }^{61}$ Other researchers have shown better therapeutic results of platelet-rich plasma (PRP) in comparison with hyaluronic acid in the treatment of TMJ-OA with long-term observation for pain reduction and mouth opening. ${ }^{62,63}$ According to Madani et al., the treatment of temporomandibular disease with low-level laser therapy (LLLT), with parameters determined in the experiment, does not show a positive effect in reducing pain and improving mouth opening in the examined patients compared to the placebo group. ${ }^{64}$ Beneficial effects are obtained by applying joint punctures, which allows reducing pain and increasing the degree of mouth opening and jaw mobility. ${ }^{65}$

\section{Juvenile idiopathic arthritis (JIA)}

It is the most common disease in pediatric rheumatology, in which TMJ is engaged in 80$87 \%$ of patients , and in $69 \%$ of cases it may be asymptomatic. ${ }^{11,66}$ Characteristic is the onset of arthritis most often before the age of 16 years, and the symptoms must last at least six weeks, but may also recur or occur for the first time in an adult. 40,67 Literature review by Kristensen et al. in 2016 on the clinical predictors of TMJ synovitis in JIA does not allow determining whether there are prognostic factors for TMD in people with JIA, due to the low level of evidence pacjenci byli mniej wrażliwi na ciepłe i zimne bodźce oraz dotyk w porównaniu z drugą grupą. Dodatkowo pacjenci z chorobą zwyrodnieniową stawów wykazywali przeczulicę ciśnieniową. ${ }^{60}$ Leczenie TMD w OA polega na złagodzeniu bólu, zapobieganiu niszczenia chrząstki i kości podchrzęstnej wraz z przywróceniem funkcji stawów. Obecnie najczęściej stosowane terapie (niesteroidowe leki przeciwzapalne - NLPZ, szynoterapia z wykorzystaniem szyn stabilizacyjnych, lasery niskopoziomowe) są skuteczne w zapobieganiu bólu i innych objawów, ale nie zmieniają patologicznej struktury stawu. Zabieg odwracający uszkodzenie ssż w OA jest w tym momencie niedostępny. ${ }^{55}$ Pozytywne wyniki leczenia zwyrodnienia stawów skroniowo-żuchwowych z przemieszczeniem krążka stawowego bez zablokowania uzyskuje się stosując iniekcje kwasu hialuronowego (HA) w górną lub dolną przestrzeń stawową. Wstrzykiwanie HA w dolną przestrzeń stawową przyczynia się do lepszej przebudowy wyrostka kłykciowego. ${ }^{61}$ Inni badacze wykazali korzystniejsze wyniki lecznicze iniekcji osocza bogatopłytkowego (PRP) w porównaniu do kwasu hialuronowego w leczeniu ssż - OA przy długoczasowej obserwacji pod kątem redukcji bólu i stopnia odwodzenia. ${ }^{62,63}$ Według Madani i wsp. leczenie choroby zwyrodnieniowej stawów skroniowo- żuchwowych za pomocą terapii niskopoziomowym laserem (LLLT), z określonymi w doświadczeniu parametrami, nie wykazuje pozytywnego efektu w zmniejszaniu bólu i poprawie otwierania ust $\mathrm{u}$ badanych pacjentów w porównaniu do grupy placebo. ${ }^{64}$ Korzystne efekty uzyskano przez zastosowanie punkcji stawu, co pozwoliło na zmniejszenie bólu oraz zwiększenie stopnia odwodzenia i ruchomości żuchwy. ${ }^{65}$

Młodzieńcze idiopatyczne zapalenie stawów MIZS (ang. juvenile idiopathic arthritis - JIA) MIZS jest najczęstszą chorobą rozpoznawaną $\mathrm{w}$ reumatologii dziecięcej, w której u 
and heterogeneity of the studies conducted so far. ${ }^{68}$ Symptoms of TMJ affected by JIA include facial pain, headaches, malocclusion, impaired chewing ability, or retrognathic mandible. ${ }^{69} \mathrm{An}$ imaging study that can conclusively diagnose acute inflammation in people with JIA is magnetic resonance imaging using a contrast agent, which is a recognized international technique. ${ }^{11}$ Importantly, even in the absence of symptoms from the TMJ, diagnostic tests should always be carried out for people with JIA. $^{70}$ In a study conducted by Kirkhus et al., it was found that people with JIA in the temporomandibular joint often develop disc abnormalities (such as flat disc, fragmentation of the disc), and the incidence was $63 \%{ }^{71}$ In the treatment of the joint affected by JIA, intraarticular corticosteroid injections are used they manifest short-term safety of use. There are fears that long-term treatment of this type may result in abnormal growth of the jaw; in order to confirm their validity it would be necessary to perform appropriate research. ${ }^{72,73}$

\section{TMD and excessive mobility of joints}

The term Ehlers-Danlos syndrome (EDS) refers to a group of genetic diseases characterized by excessive joint flexibility and coexisting impaired wound healing. There are ten types of EDS. In this syndrome, we can observe increased mobility of the temporomandibular joint. We can also observe movements in planes other than physiological. ${ }^{74}$

De Coster et al. assessed oral health in 31 people with various types of EDS (16 with excessive, 9 with classic, 6 with vascular mobility) - including TMD symptoms. All patients had symptoms of TMD and reported chronic dislocations of the TMJ. The authors claimed that these pathologies resulted from connective tissue defects in the craniofacial structures. ${ }^{75}$

De Coster et al. also studied the relationship
80-87\% pacjentów dochodzi do zajęcia stawów skroniowo-żuchwowych, a w $69 \%$ przypadków może mieć przebieg bezobjawowy. ${ }^{11,66}$ Charakterystyczne dla niej jest wystąpienie początkowego zapalenia stawów najczęściej przed ukończeniem 16-ego roku życia, objawy muszą trwać co najmniej 6 tygodni, ale mogą również mieć charakter nawrotowy lub wystąpić pierwszy raz u dorosłej osoby. ${ }^{40,67}$ Przegląd literatury przeprowadzony przez Kristensena i wsp. z 2016 roku dotyczący klinicznych predyktorów zapalenia stawów skroniowo-żuchwowych w MIZS nie pozwala ustalić, czy istnieją czynniki prognostyczne dla TMD u osób z MIZS, ze względu na niski poziom dowodów oraz heterogeniczność przeprowadzonych dotychczas badań. ${ }^{68}$ Do objawów występujących w ssż w przebiegu MIZS zalicza się bóle twarzy, głowy, wady zgryzu, upośledzenie zdolności żucia, czy retrognatyczną żuchwę. ${ }^{69}$ Badaniem obrazującym pozwalającym jednoznacznie zdiagnozować ostre zapalenie u osób z MIZS jest rezonans magnetyczny z użyciem środka kontrastowego. ${ }^{11}$ Co ważne, nawet przy braku objawów ze strony ssż, należy zawsze wdrażać badania diagnostyczne $\mathrm{w}$ przypadku osób z MIZS. ${ }^{70} \mathrm{~W}$ badaniu przeprowadzonym przez Kirkhus i wsp. stwierdzono, że u osób z MIZS w stawie skroniowo-żuchwowym często dochodzi do nieprawidłowości krążkowych (np: płaski krążek, fragmentacja krążka), a częstość występowania wynosiła $63 \%{ }^{71} \mathrm{~W}$ leczeniu stawu zajętego przez MIZS stosowane są wewnątrzstawowe iniekcje kortykosteroidowe, istnieją jednak obawy, że długoterminowe leczenie tego typu może skutkować zaburzeniem wzrostu żuchwy. ${ }^{72,73}$

\section{TMD a nadmierna mobilność stawów}

Pod nazwą zespół Ehlersa-Danlosa (EDS) kryje się grupa chorób genetycznych, które charakteryzują się nadmierną elastycznością stawów i współistniejącym utrudnionym gojeniem ran. Wyróżnia się 10 typów EDS. 
between generalized joint hypermobility (GJH) and TMD. The group of patients with GMJ included those with GJH syndrome, but also with EDS and Marfan syndrome. In patients with GJH, as many as $71.4 \%$ of the subjects had symptoms of TMD, however only $13.3 \%$ sought help. The symptoms were dominated by disc displacement without reduction (DDwoR), (in $85.7 \%$ diagnosed with TMD), myofascial pain (in $69 \%$ of respondents, or TMJ pain $61.9 \%) .{ }^{76}$ Diagnostic criteria for EDS are joint pain lasting over three months in a minimum of four joints and obtaining, among others, the score of 4 out of 9 on the Beighton scale. Diagnostic tests can be performed to confirm EDS. It should be remembered that during treatmentof EDS, attention should be focused on the weakening of periodontal ligaments (orthodontic treatment). ${ }^{77,78}$ In their article, Létourneau et al. stress that in patients with this syndrome the mitral valve flap may fall out a. It should be considered during planning dental procedures and a prophylactic antibiotic should be administered. It is also recommended that dental visits should be as short as possible to minimize the risk of iatrogenic injury to the patient. Ideally, surgery should be avoided due to abnormalities in wound healing and scarring. However, if it proves necessary, it is recommended to check the patient's blood clotting capacity. It is also recommended that the stitches applied after surgery which fail to approximate the wound edges properly, should be covered with acrylic bandage. ${ }^{78,79}$

Generalized joint mobility is an increase in joint mobility beyond accepted levels. Berger et al. conducted research by means of the RDC/ TMD questionnaire used for TMD diagnostics. Researchers defined GJH using the Beighton scale and failed to show the relationship between TMD and GJH. However, using the r-Pearson scale, they showed a connection. Studies conducted by Perrini et al. also suggest a correlation between those two ailments. ${ }^{80,81}$
W zespole tym można zaobserwować zwiększoną ruchomość stawów skroniowo-żuchwowych, z możliwością wystąpienia ruchów żuchwy w zakresie innym niż fizjologiczne. ${ }^{74}$

De Coster i wsp. oceniali stan zdrowia jamy ustnej u 31 osób z różnymi typami EDS (16 z nadmierną ruchomością, 9 z klasyczną, 6 z naczyniową) - w tym oznaki TMD. Wszyscy pacjenci mieli symptomy TMD i zgłaszali przewlekłe zwichnięcia ssż. Zmiany te uznano jako skutek defektów tkanki łącznej w strukturach części twarzowej czaszki. ${ }^{75} \mathrm{De}$ Coster i wsp. badali też związek pomiędzy uogólnioną hipermobilnością stawów (GJH) a TMD. W grupie badanych znaleźli się chorzy z zespołem GJH, ale i z EDS oraz syndromem Marfana. U osób z GJH aż 71,4\% badanych miało symptomy TMD, jednakże tylko 13,3\% chorych szukało pomocy. W objawach dominowała dyslokacja krążka z zablokowaniem (u 85,7\% zdiagnozowanych z TMD), ból mięśniowo-powięziowy (u 69\% badanych; czy bóle ssż $-61.9 \%) .{ }^{76}$ Kryteria diagnostyczne EDS obejmują: ból stawów trwający powyżej 3 miesięcy w minimum 4 stawach oraz uzyskanie m.in. 4 na 9 w skali Beightona. Do potwierdzenia diagnostycznego EDS można wykonać badania genetyczne. Należy pamiętać by przeprowadzając zabiegi u osób z EDS, zwrócić uwage na osłabienie więzadeł przyzębia (leczenie ortodontyczne). ${ }^{77,78}$ Létourneau i wsp. w swoim artykule przypominają, że u chorych z tym syndromem może wypadać płatek zastawki mitralnej, co należy wziąć pod uwagę przy planowaniu zabiegów stomatologicznych i zastosować profilaktycznie antybiotyk. Ponadto zalecaja też aby wizyty stomatologiczne były jak najkrótsze, by zminimalizować ryzyko stworzenia jatrogennego urazu u pacjenta. Idealnie byłoby unikać operacji ze względu na nieprawidłowości w gojeniu się ran i bliznowaceniu. Jeżeli jednak operacja okaże się konieczna, to zaleca się sprawdzenie krzepliwości krwi u chorego. Poleca się też by „nietrzymające” się szwy, 
In the relief of pain in TMD in patients with EDS or generalized joints hypermobility, we can use physical treatments such as heat therapy, cold therapy, and massages. In the therapy of pain in patients with EDS, the NSAID painkillers are effective in some patients; for some patients the episodes are so painful that it is necessary to use opioid drugs. Importantly, patients with EDS often have fears and depression, thus the psychological aspect of treating this disease should not be ignored. ${ }^{79}$

\section{TMD and headache}

Headache is the most common neurological disease in the population, falling into primary and secondary category. ${ }^{82,83}$ TMD can also occur in primary headaches such as tension headache and migraine. ${ }^{83}$ The International Headaches Society stated that secondary headaches are a characteristic feature of TMJrelated disorders. According to studies, up to $67.5 \%$ of patients with TMD suffer from headaches. There are many studies confirming the comorbidity of headaches and TMD. In one of the studies in the group of people, in whom TMD was manifesting with pain, the frequency of reported headaches was as high as $82.8 \%{ }^{82,83}$

\section{Tension headache}

Tension type headache (TTH) is the most common primary headache affecting $21.8 \%$ of the population. Its cause is increased tension of the head and neck muscles. This pain often displays a bilateral character, the patient feels pressure on the head, its intensity is mild or medium, lasting up to several hours. As opposed to migraine, it is not perceived as pulsating. ${ }^{85,86}$ According to research by Franco et al., TTH may affect up to $30.2 \%$ of patients with TMD. Emshoff et al. evaluated the coexistence of TMD and tension headache. It connected both diseases and also highlighted their common aspect: mental and emotional które zostały w wyniku zabiegu założone, pokryć akrylowym opatrunkiem. ${ }^{78,79}$

Uogólnioną mobilność stawów rozumie się jako wzrost ruchomości stawów poza przyjęte normy. Berger i wsp. przeprowadzili badania z użyciem kwestionariusza RDC/TMD stosowanego $\mathrm{w}$ diagnostyce TMD. Badacze definiowali GJH z użyciem skali Beightona i nie wykazali związku między TMD a GJH, podczas gdy posługując się skalą r-Pearsona stwierdzono takie powiązanie. Badania przeprowadzone przez Perrini'ego i wsp. również sugerują korelację między TMD a GJH. ${ }^{80,81} \mathrm{~W}$ łagodzeniu bólu w TMD u pacjentów z EDS lub hipermobilnością uogólnioną można wykorzystać zabiegi fizykalne, takie jak terapia ciepłem, terapia zimnem, masaże. W terapii bólu u pacjentów z EDS sprawdzają się leki przeciwbólowe z grupy NLPZ, lecz dla niektórych epizody są na tyle bolesne, że konieczne jest wykorzystanie leków opioidowych. Co istotne u pacjentów z EDS często współwystępują lęki oraz depresja, dlatego należy zadbać o psychologiczny aspekt leczenia tej choroby. ${ }^{79}$

\section{TMD a ból głowy}

Bóle głowy są najczęściej występującym w populacji problem neurologicznym, dzielą się one na pierwotne i wtórne. ${ }^{82,83}$ TMD może występować w pierwotnych bólach głowy, takich jak napięciowy ból głowy czy migrena. ${ }^{83}$ International Headaches Society uznało, że wtórne bóle głowy są cechą przypisaną do zaburzeń związanych z ssż. Według badań aż $67,5 \%$ pacjentów z TMD odczuwa bóle głowy. Istnieje wiele badań potwierdzających współwystępowanie bólów głowy i TMD. W jednym $\mathrm{z}$ badań w grupie osób, u których TMD objawiało się bólem, częstotliwość zgłaszanych bólów głowy wynosiła aż 82,8\%. ${ }^{82,83}$

\section{Napięciowy ból głowy}

Napięciowy ból głowy (TTH) jest najpowszechniejszym pierwotnym bólem głowy 
state of patients. Half of the TMD patients they examined experienced tension headaches. What is more, by using a specially designed questionnaire they showed a significant link between TTH and depression. ${ }^{83,87}$ TTH is a pain that is treated with aspirin and ibuprofen. Due to the etiology of this pain, associated with TMD, splint therapy may be beneficial in this type of cases. Studies carried out by Kostrzewa-Janicka et al. showed pain relief by 3 points in as many as $61.8 \%$ of patients with headache! ${ }^{88}$ Physiotherapeutic treatments are also useful in the treatment of TMD. Available data demonstrate the usefulness of electrotherapy because the indications for its use include pain and increased muscle tone (we use TENS/hyaluronidase iontophoresis). It also reduces muscle strength in people with hypermobility (electrostimulation). ${ }^{89}$

\section{Migraine}

Migraine is a chronic headache characterized by repeating attacks. The most common migraine pain is typically one-sided, pulsating and varying in intensity, lasting even for up to several days. ${ }^{90}$ The etiology of migraine is not fully understood, but the most probable cause is the genetic hypersensitivity of neurons (about $2 / 3$ of migraine cases are familial). Migraine can also be triggered by stress, hunger, fatigue, and also hormonal factors such as pregnancy, menopause and the occurrence of menarche. ${ }^{91,92}$ According to studies, TMD and migraine are comorbid diseases. ${ }^{93}$ The prevalence of TMD in migraine patients was $56.1 \%$, and a higher incidence of TMD was found in the group with combined migraine and tension headache. ${ }^{84}$ In the treatment of migraine, analgesics such as acetylsalicylic acid (650-1300 mg), paracetamol (650-1300 mg), ibuprofen (1200$1800 \mathrm{mg}$ ) are most commonly used. Others include ergotamine preparations, antiemetics or those acting on the serotonogenic system. The migraine-causing factor should be identificated
- dotyczy on 21,8\% populacji. Jego przyczyną jest zwiększone napięcie mięśni głowy i szyi. Ból ten jest zlokalizowany najczęściej obustronnie, trwa do kilku godzin, pacjent czuje uciskowe opasanie głowy, jego nasilenie może być łagodne lub umiarkowane. W odróżnieniu od migreny nie jest odczuwalny jako pulsujący. ${ }^{85,86}$ Według badań Franco i wsp. TTH może dotyczyć nawet 30,2\% chorych z TMD, natomiast Emshoff i wsp. oceniali współistnienie TMD i napięciowego bólu głowy - przeprowadzone badanie powiązało nie tylko oba schorzenia, ale także zwróciło uwagę na kluczowy dla obu schorzeń aspekt, a mianowicie stan psychiczny i emocjonalny pacjentów. Połowa badanych przez nich pacjentów z TMD doświadczała napięciowych bólów głowy. Ponadto, dzięki użyciu specjalnych formularzy wykazano istotne powiązanie między TTH a depresją. ${ }^{83,87} \mathrm{TTH}$ jest bólem, który poddaje się leczeniu aspiryną i ibuprofenem. Ze względu na skojarzenie bólu z TMD, w przypadkach takich korzystna może być szynoterapia. Badania przeprowadzone przez Kostrzewe-Janicka i wsp. wykazały zmniejszenie bólu o 3 punkty wynikowe aż u $61,8 \%$ z bólem głowy. ${ }^{88} \mathrm{~W}$ leczeniu przydatne są również zabiegi fizykoterapeutyczne oraz elektroterapia, ponieważ wskazaniami do jej zastosowania są dolegliwości bólowe i wzmożone napięcie mięśniowe (TENS/jonoforeza hialuronidazowa), ponadto do zmniejszenia siły mięśniowej u osób z hipermobilnością stosowana jest elektrostymulacja. ${ }^{89}$

\section{Migrena}

Migrena jest przewlekłym bólem głowy, charakteryzującym się powtarzającymi się atakami, najczęściej występującym jednostronnie, pulsującym o różnej intensywności, trwającym nawet kilka dni. ${ }^{90}$ Etiologia migreny nie jest do końca wyjaśniona, natomiast za prawdopodobną przyczynę uważa się genetyczną nadwrażliwość neuronów (około $2 / 3$ przypadków migreny występuje rodzinnie). Migrena może 
and eliminated. Also useful are changes in habits, psychotherapy, using relaxation techniques or re-education. ${ }^{79}$ Treatment of migraines coexisting with TMD should be comprehensive, involving various specialists. The best way to treat migraine with co-existing TMD has not been determined yet, however, some studies, including those performed by Gonçalves et al., point out that if migraine occurs with TMD, migraine pain will be reduced if both conditions undergo treatment. ${ }^{94}$

\section{TMD and estrogen level}

Statistically, temporomandibular disorders occur more often in women. ${ }^{4-6}$ Hence, many scientists have conducted studies, whose aim was to show whether there is any correlation between estrogen levels and the incidence of TMD. Estrogen receptors are found in the tissues of the nervous system - including the neural tissue of the trigeminal nerve. It is believed that estrogen plays a role in the modulation of pain signals. ${ }^{95}$ Rui-Yun et al., in their studies on the influence of 17-betaestradiol in ratsshowed that it can cause hypersensitivity of the temporomandibular joint undergoing inflammation. ${ }^{96}$ It is known that estrogen receptors are present in the temporomandibular joint in the cartilaginous condylar tissue. ${ }^{97}$ Yasutoka et al. and Chang et al. studied the effect of estrogen deficiency on temporomandibular joint (which they observed following the removal of ovaries in rat females). They observed the following structural changes: reduction of subchondral bone volume, increase of cartilage thickness, and even serial degenerative changes. ${ }^{98,99}$ On the other hand, Landi et al. studied the concentration of 17-beta-estradiol in subjects with TMD (group II and/or III RDC/TMD) and without TMD in both sexes. The results of the experiment showed that the concentration of estrogen in plasma was significantly above the norm in people with temporomadibular być też wywołana przez wyzwalacze, takie jak stres, głód, zmęczenie a także czynniki hormonalne (ciąża, menopauza, wystąpienie pierwszej miesiączki). ${ }^{91,92}$ Według badań TMD i migreny są przypadłościami współwystępującymi. ${ }^{93}$ Częstość występowania TMD u pacjentów z migreną wynosiła 56,1\%, a wyższą częstość występowania TMD wykryto w grupie $\mathrm{z}$ połączoną migreną i napięciowym bólem głowy. ${ }^{84} \mathrm{~W}$ leczeniu migreny najczęściej stosuje się leki przeciwbólowe, takie jak kwas acetylosalicylowy $650-1300 \mathrm{mg}$, paracetamol 650-1300 mg, ibuprofen 1200-1800 mg. Wskazane są też preparaty ergotaminy, leki przeciwwymiotne czy też działające na układ serotogeniczny. Należy starać się zidentyfikować czynnik powodujący migrenę i go wyeliminować, przydatna okazuje się zmiana nawyków, psychoterapia, stosowanie technik relaksacyjnych czy reedukacja. ${ }^{79}$ Nie odnaleziono jeszcze najlepszego sposobu na leczenie migreny z współistniejącym TMD, jednakże badania wykonane przez Gonçalves i wsp. zwracają uwagę, że u osób chorujących na migrenę wraz z TMD, bóle migrenowe ulegają redukcji, jeżeli leczone są oba stany chorobowe. ${ }^{94}$

\section{TMD a estrogen}

Dysfunkcje ssż statystycznie częściej występują u kobiet. ${ }^{4-6}$ Stąd wielu naukowców przeprowadzało badania mające na celu wykazanie czy pomiędzy poziomem estrogenów a częstotliwością występowania TMD zachodzi jakiś związek. Receptory estrogenowe znajdują się też w tkankach układu nerwowego - w tym w tkance nerwowej nerwu trójdzielnego. Podejrzewa się, że estrogen odgrywa rolę $\mathrm{w}$ modulacji sygnałów bólowych. ${ }^{95}$ Rui-Yun i wsp. w swoich badaniach dotyczących wpływu 17-beta-estradiolu u szczurów wykazali, że może on powodować przeczulicę stawu skroniowo-żuchwowego i rozwój zapalenia..$^{96}$ Wiadomo, że receptory estrogenowe są obecne w stawie skroniowo-żuchwowym w tkance 
dysfunction in both sexes. ${ }^{100}$ Research carried out by Kostrzewa-Janicka et al. showed that women taking combined oral contraceptives treated for temporomandibular joint disorders have less chance of better treatment outcome than women who do not take contraceptives, which indicates the role of hormonal factors in women causing modification of treatment efficacy. ${ }^{101}$ Studies on the relationship between levels of this hormone and the occurrence of TMD are not standardized as to the method, some provide divergent or even contradictory data. ${ }^{95}$ Future studies should also consider the double effect of estrogen. ${ }^{91}$ It can be concluded that currently the effect of estrogens on TMD is not fully explain, however, the evidence of this theory would help to direct research on TMD towards endocrine disorders.

\section{Conclusion}

Because of the variety of conditions that may co-exist with TMD, and those that cause TMD, it is important that the doctor treats the patient holistically and applies not only symptomatic treatment, but also tries to treat the underlying cause. This is the only approach that can lead to positive treatment outcome. chrzęstnej kłykcia. ${ }^{97}$ Yasutoka i wsp. oraz Cheng i wsp. badali wpływ niedoboru estrogenu na ssż (stan ten uzyskali usuwając jajniki samicom szczura), obserwując takie zmiany strukturalne jak: zmniejszenie objętości kości podchrząstkowej, zwiększenie grubości chrząstki, a nawet seryjne zmiany zwyrodnieniowe. ${ }^{98,99}$ Natomiast Landi i wsp. badali stężenie 17-beta-estradiolu u osób z TMD (grupa II i/lub IIIRDC/TMD) i bez TMD obu płci. Wyniki doświadczenia wykazały, że stężenie tego hormonu w osoczu było znacząco powyżej normy u osób z dysfunkcją ssż obu płci. ${ }^{100}$ Badania przeprowadzone przez Kostrzewę-Janicka i wsp. wykazały, że kobiety przyjmujące złożone doustne środki antykoncepcyjne $\mathrm{z}$ prowadzonym leczeniem zaburzeń stawów skroniowo-żuchwowych, mają mniejsze szanse na poprawę niż kobiety nie przyjmujące środków antykoncepcyjnych, co wskazuje na rolę czynników hormonalnych w skuteczności leczenia. ${ }^{101}$ Należy rozważyć w przyszłych badaniach działanie estrogenu zależne od polimorfizmu jego receptorów. ${ }^{91}$ Można uznać, że aktualnie wpływ estrogenów na TMD nie jest do końca zbadany i potwierdzenie tego faktu pomogłoby ukierunkować badania dotyczące TMD, z uwzględnieniem zaburzeń endokrynologicznych.

\section{Podsumowanie}

Ze względu na rozmaitość schorzeń, które mogą współwystępować z TMD oraz takich, które je powodują - istotne jest aby lekarz podchodził do pacjenta holistycznie, stosując nie tylko leczenie symptomatyczne, ale także niwelujące przyczyny. Całościowe spojrzenie na pacjenta pozwoli uzyskać pozytywny efekt terapeutyczny.

\section{References / Piśmiennictwo}

Dostępne w Redakcji i na www.protetstomatol.pl
Zaakceptowano do druku: 21.02.2019 r. Adres autorów: 41-902 Bytom, Pl. Akademicki 17.

(C) Zarząd Główny PTS 2019. 


\section{References / Piśmiennictwo}

1. Górecka $M$, Pihut $M$, Ferendiuk $E$ : Charakterystyka schorzeń stawów skroniowo-żuchwowych. Dental Forum 2016; 64(1).

2. Berger M, Oleszek-Listopad J, Marczak M, Szymańska J: Psychological aspects of temporomandibular disorders - literature review. Curr Issues Pharm Med Sci 2015; 28(1): 55-59.

3. Büttner P, Czarnecka B, Shaw H: Zastosowanie terapii manualnej w leczeniu dysfunkcji stawu skroniowo żuchwowego. Czas Stomatol 2008; 61(11): 807-814

4. Manfredini D, Guarda-Nardini L, Winocur E, Piccotti F, Ahlberg FJ, Lobbezoo F: Oral surgery, oral medicine, oral pathology, oral radiology, and endodontics. 2011; 112(4): 453-462.

5. Liu F, Steinkeler A: Epidemiology, Diagnosis and Treatment of Temporomandibular Disorders Dent Clin 2013; 53: 465-479.

6. Bi RY, Ding Y, Gan YH: A new hypothesis of sex-differences in temporomandibular disorders:Estrogen enhances hyperalgesia of inflamed TMJ through modulating voltagegated sodium channel 1.7 in trigeminal ganglion. Med Hypotheses 2015; 84: 100-103.

7. Baron S, Sala M, Proba T, Baron A, Przybytek T: Rehabilitacja protetyczno-czynnościowa po jatrogennym leczeniu protetycznym - opis przypadku. Mag Stomatol 2011; 21(2): 20-24.

8. Johansson A, Unell L, Carlsson GE, Söderfeldt $B$, Halling $A$ : Gender difference in symptoms related to temporomandibular disorders in a population of 50-year-old subjects. J Orofac Pain 2003; 17(1): 29-35.

9. Kotlarska A: Dysfunkcje układu ruchowego narządu żucia - etiologia i leczenie. Stomatol Współcz 2012; 19(3): 41-45.

10. Ferreiraa LA, Grossmanne E, Januzzih E, de Paulai MVQ, Carvalhod ACP: Diagnosis of temporomandibular joint disorders: indication of imaging exams. Braz J Otorhinolaryngol 2016; 82(3): 341-352.

11. Koos B, Tzaribachev N, Bott S, Ciesielski R, Godt A: Classification of temporomandibular joint erosion, arthritis, and inflammation in patients with juvenile idiopathic arthritis. J Orofac Orthop 2013; 74: 506-519.

12. Śliwa A: Przemieszczenia krążka stawowego jako czynnik etiologiczny powstawania zaburzeń czynnościowych narządu żucia. Porad Stomatol 2007; 7(6): 187-191.

13. Magdziak M, Kostrzewa-Janicka J, Mierzwińska-Nastalska E, Zadurska M: Znaczenie leczenia ortodontycznego w etiologii i terapii dysfunkcji w obrębie układu ruchowego narządu żucia - na podstawie piśmiennictwa. Protet Stomatol 2013; 63(1): 4959.

14. Osiewicz MA, Lobbezoo F, Loster BW, Wilkosz $M$, Naeije $M$, Ohrbach E: Badawcze Kryteria Diagnostyczne Zaburzeń Czynnościowych Układu Ruchowego Narządu Żucia BKD/ ZCURNŻ - polska wersja dwuosiowego systemu diagnostycznego ZCURNŻ. Formularz BKD/ZCURNŻ. J Stomatol 2013; 66(5): 576592.

15. Jagucka-Mętel W, Brzeska P, Kijak E, LieczKijak D, Machoy-Mokrzyńska A, Bułatwocicz I, Soblewska E: Terapia dysfunkcji układu ruchowego narządu żucia - problem interdyscyplinarny. Mag Stom 2013; 1.

16. Piecha M: Fizjoterapia w stomatologii. Twój Przegląd Stomatologiczny 2011; 11.

17. Poveda RR, Bagán JV, Díaz Fernández JM, Hernández-Bazán S, Jiménez-Soriano $Y$ : Review of temporomandibular joint pathology. Part I: Classification, epidemiology and risk factors. Med Oral Patol Oral Cir Bucal 2007; 12: 292-288.

18. Jankowska K, Split W: Kryteria diagnostyczne zaburzeń układu ruchowego narządu żucia - RDC/TMD opracowane przez Dworkina 
i LeResche. Charakterystyka i uwagi. Mag Stomatol 2014; 24(9): 34-38.

19. Kleinrok $M$ : Zaburzenia czynnościowe układu ruchowego narządu żucia. Lublin 2012.

20. Pihut M, Szewczyk M, Wiśniewska G, Gala A: Ocena przydatności kwestionariusza McGillaMelzacka w diagnostyce doznań bólowych u pacjentów z zaburzeniami czynnościowymi układu stomatognatycznego - doniesienie wstępne. Porad Stomatol 2012; 12(2): 70-75.

21. Mierzwińska-Nastalska E: Diagnostyka układu ruchowego narządu żucia. Med Tour Press International. Warszawa 2009.

22. Klatkiewicz T, Gawriotek K, PobudekRadzikowska M, Czajka-Jakubowska A: Ultrasonography in the Diagnosis of Temporomandibular Disorders: A MetaAnalysis. Med Sci Monit 2018; 24: 812-817

23. Łapuć M, Gotębiewska M, Sierpińska T: Zastosowanie badań EMG i T-Scan w diagnostyce pacjentów z dysfunkcją układu ruchowego narządu żucia. Mag Stomatol 2008; 18(4): 24-28.

24. Rakowiecka M, Lewandowski J: Zastosowanie zabiegów fizykoterapeutycznych oraz aplikacji kinesiology taping** $\mathrm{R}$ u pacjentów $\mathrm{z}$ dysfunkcją narządu żucia. Mag Stomatol 2015; 25(2); 95-98.

25. Baron S, Krzemień J, Baron A, Dzierżon A: Nowoczesne metody szynoterapii w leczeniu dysfunkcji urnż. e-Dentico 2009; 4(24): 18 24.

26. Chruściel-Nogalska M, Polak-Majcher D, Dalewski B, Frączak B: Przegląd stosowanych szyn zgryzowych w zleczeniu zaburzeń czynnościowych układu stomatognatycznego - na podstawie piśmiennictwa. Dental Forum 2013; XLI, 2: 63-68.

27. Kothari SF, Baad-Hansen L, Svensson P: Psychosocial Profiles of Temporomandibular Disorder Pain Patients: Proposal of a New Approach to Present Complex Data. J Oral Facial Pain Headache 2017; 31(3): 199-209.

28. Rugh JD: Psychological factors in the etiology of masticatory pain and dysfunction. The President's Conference on the Examination, Diagnosis and Management of Temporomandibular Disorders. Amer Dent Ass 1982; 85: 1-4.

29. Lei J, Fu J, Yap AU, \& Fu $K Y$ : Temporomandibular disorders symptoms in Asian adolescents and their association with sleep quality and psychological distress. Cranio 2016; 34(4): 242-249.

30. Manfredini D, Marini M, Pavan C, Pavan L, Guarda-Nardini L: Psychosocial profiles of painful TMD patients. J Oral Rehabil 2009; 36(3): 193-198.

31. Fernandes $G$, Gonçalves $\quad D A$, de Siqueira JT, Camparis CM: Painful temporomandibular disorders, self reported tinnitus, and depression are highly associated. Arq Neuropsiquiatr 2013; 71(12): 943-947.

32. Oliveira LK, Almeida $G$ de A, Lelis ÉR, Tavares $M$, Fernandes Neto AJ: Temporomandibular disorder and anxiety, quality of sleep, and quality of life in nursing professionals. Braz Oral Res 2015; 29.

33. Vedolin GM, Lobato VV, Conti PC, Lauris $J R$ : The impact of stress and anxiety on the pressure pain threshold of myofascial pain patients. J Oral Rehabil 2009; 36(5): 313-321.

34. Mottaghi A, Razavi SM, Pozveh EZ, Jahangirmoghaddam M: Assessment of the relationship between stress and temporomandibular joint disorder in female students before university entrance exam (Konkour exam). Dent Res J (Isfahan) 2011; 8(11): 76-79.

35. Manfredini D, Bandethini AB, Cantini E: Mood and anxiety Psychopathology and temporomandibular disorder. J Oral Rehabil 2009; 41: 933-937.

36. Madani A, Mehdizade F: Investigating the prevalence of TMD risk factors in 100 patients referred to dental faculty of Mashhad University. J Shahid Beheshti Univ 2003; 2: 229-237.

37. Kijak M: Stres. 15 najskuteczniejszych spo- 
sobów na radzenie sobie ze stresem. Złote Myśli. Gliwice 2009.

38. Wright EF, North SL: Management and Treatment of Temporomandibular Disorders: A Clinical Perspective. J Man Manip Ther 2009; 17(4): 247-254.

39. Büttner P, Czarnecka B, Shaw H: Zastosowanie terapii manualnej $\mathrm{w}$ leczeniu dysfunkcji stawu skroniowo żuchwowego. Czas Stomatol 2008; 61, 11: 807-814

40. Gajewski P, Szczeklik A: Interna Szczeklika. MP Kraków 2015.

41. Kwiatkowska B, Raciborki F, Maślińska M, Kłak A, Grylewicz J, Samel-Kowalik P: Wczesna diagnostyka chorób reumatycznych-ocena obecnej sytuacji i rekomendacje zmian. Instytut Reumatologii im. prof. dr hab. med. Eleonory Reicher, Warszawa 2014.

42. Iordache C, Ghiorghe CA, Ancuța C: Epidemiology of temporomandibular joint involvement In rheumatic pathology. Rom J Oral Rehabil 2017; 9(3).

43. Hoyuela CP, Furtado RN, Chiari A, Natour $J$ : Oro-facial evaluation of women with rheumatoid arthritis. J Oral Rehabil 2015; 42(5): 370-377.

44. Scott DL, Wolfe F, Huizinga TW: Rheumatoid arthritis. Lancet 2010; 376(9746): 1094-1108.

45. Cordeiro PC, Guimaraes JP, de Souza VA, Dias IM, Silva JN, Devito KL, Bonato LL: Temporomandibular joint involvement in rheumatoid arthritis patients: association between clinical and tomographic data. Acta Odontol Latinoam 2016; 29(3): 123-129.

46. Witulski S, Vogl TJ, Rehart S, Ottl P: Evaluation of the TMJ by means of Clinical TMD Examination and MRI Diagnostics in Patients with Rheumatoid Arthritis. BioMed Res Int 2014; 2014.

47. SodhiA, NaikS,PaiA, AnuradhaA: Rheumatoid arthritis affecting temporomandibular joint. Contemp Clin Dent 2015; 6(1): 124-127.

48. Ahmed N, Mustafa HM, Catrina AI, Alstergren $P$ : Impact of Temporomandibular Joint Pain in Rheumatoid Arthritis. Acta Odontol Scand 2003; 61(5): 278-282.

49. Larheim TA, Abrahamsson AK, Kristensen M, Arvidsson LZ: Temporomandibular joint diagnostics using CBCT. Dentomaxillofac Radiol 2015; 44(1).

50. Hirahara N, Kaneda T, Muraoka H, Fukuda T, ItoK, KawashimaY:CharacteristicMagnetic Resonance Imaging Findings in Rheumatoid Arthritis of the Temporomandibular Joint: Focus on Abnormal Bone Marrow Signal of the Mandibular Condyle, Pannus, and Lymph Node Swelling in the Parotid Glands. Publication: J Oral Maxillofac Surg 2017; 75(4): 735-741.

51. Kretapirom K, Okochi K, Nakamura S, Tetsumura A, Ohbayashi N, Yoshino N, Kurabayashi T: MRI characteristics of rheumatoid arthritis in the temporomandibular joint. Dentomaxillofac Radiol 2013; 42(4).

52. Gabriel SE, Michaud K: Epidemiological studies in incidence, prevalence, mortality, and comorbidity of the rheumatic diseases. Arthritis Res Ther 2009; 11(3): 229.

53. Rodrigues $D B$, Wolford LM, Malaquias $P$, Campos PS: Concomitant treatment of mandibular ameloblastoma and bilateral temporomandibular joint osteoarthritis with bone graft and total joint prostheses. J Oral Maxillofac Surg 2015; 73(1): 63-74.

54. Zhang X, Chen F, Chen L, Li B, Xu S, Cui D, Yu L, Liu M, Shi X, Li Q, Li Y: Symptoms and signs of temporomandibular disorders in patients with knee osteoarthritis. Int Dent J 2017; 67: 78-84.

55. Wang XD, Zhang JN, Gan YH, Zhou YH: Current Understanding of Pathogenesis and Treatment of TMJ Osteoarthritis. J Dent Res 2015; 94(5): 666-673.

56. Dias IM, Cordeiro PC, Devito KL, Tavares $M L$, Leite IC, Tesch $R$ de $S$ : Evaluation of temporomandibular joint disc displacement as a risk factor for osteoarthrosis. Int J Oral Maxillofac Surg 2016; 45(3): 313-317. 
57. Cömert KS, Kiliç N, Sümbüllü MA: Temporomandibular joint osteoarthritis: cone beam computed tomography findings, clinical features, and correlations. Int J Oral Maxillofac Surg 2015; 44(10): 1268-1274.

58. Zheng ZW, Yang C, Wang MH, Zhu XH, Fang $Y M$ : Non-joint effusion is associated with osteoarthritis in temporomandibular joints with disk displacement. J Craniomaxillofac Surg 2016; 44(1): 1-5.

59. Cevidanes LHS, Gomes LR, Jung BT, Gomes $M R$, Ruellas ACO, Goncalves JR, Schilling $J$, Styner M, Nguyen T, Kapila S, Paniagua $B$ : 3D superimposition and understanding temporomandibular joint arthritis. Orthod Craniofac Res 2015; 18(1): 18-28.

60. Kothari SF, Baad-Hansen L, Hansen LB, Bang $N$, Sorensen LH, Eskildsen HW, Svensson P: Pain profiling of patients with temporomandibular joint arthralgia and osteoarthritis diagnosed with different imaging techniques. J Headache Pain 2016; 17(1): 61.

61.Li C, Long X, Deng M, Li J, Cai H, Meng $Q$ : Osteoarthritic changes after superior and inferior joint space injection of hyaluronic acid for the treatment of temporomandibular joint osteoarthritis with anterior disc displacement without reduction: a cone-beam computed tomographic evaluation. J Oral Maxillofac Surg 2015; 73(2): 232-244.

62. Hegab AF, Ali HE, Elmasry M, Khallaf MG: Platelet-Rich Plasma Injection as an Effective Treatment for Temporomandibular Joint Osteoarthritis. J Oral Maxillofac Surg 2015; 73(9): 1706-1713.

63. Cömert KS, Güngörmüş $M$, Sümbüllü $M A$ : Is Arthrocentesis Plus Platelet-Rich Plasma Superior to Arthrocentesis Alone in the Treatment of Temporomandibular Joint Osteoarthritis? A Randomized Clinical Trial. J Oral Maxillofac Surg 2015; 73(8): 14731483.

64. Madani AS, Ahrari F, Nasiri F, Abtahi M, Tunér
$J$ : Low-level laser therapy for management of TMJ osteoarthritis. Cranio 2014; 32(1): 3844.

65. Leibur E, Jagur O, Voog-Oras $\ddot{U}$ : Temporomandibular joint arthrocentesis for the treatment of osteoarthritis. Stomatologija. 2015; 17(4): 113-137.

66. Foeldvari I, Tzaribachev N, Cron RQ: Results of a multinational survey regarding the diagnosis and treatment of temporomandibular joint involvement in juvenile idiopathic arthritis. Pediatr Rheumatol Online J 2014; 25, 12: 6 .

67. Kim KH, Kim DS: Juvenile idiopathic arthritis: Diagnosis and differential diagnosis. Korean J Pediatr 2010; 53(11): 931-935.

68. Kristensen KD, Stoustrup $P$, Küseler A, Pedersen TK, Twilt M, Herlin T: Clinical predictors of temporomandibular joint arthritis in juvenile idiopathic arthritis: A systematic literature review. Semin Arthritis Rheum 2016; 45(6): 717-732.

69. Meyers $A B$, Laor $T$ : Magnetic resonance imaging of the temporomandibular joint in children with juvenile idiopathic arthritis. Pediatr Radiol 2013; 43(12): 1632-1141.

70. Figueiredo-Zwir LML, Terreri MTRA, Sousa $S A$, Fernandes AR, Guimarães AS, Hilário $M O$ : Are temporomandibular joint signs and symptoms associated with magnetic resonance imaging findings in juvenile idiopathic arthritis patients? A longitudinal study. Clinical Rheumatology. Springer Nature 2015; 1.

71. Kirkhus E, Arvidsson LZ, Smith HJ, Flato B, Hetlevik SO, Larheim TA: Disk abnormality coexists with any degree of synovial and osseous abnormality in the temporomandibular joints of children with juvenile idiopathic arthritis. Pediatr Radiol 2016; 46(3): 331-341.

72. Stoustrup P, Kristensen KD, Verna C, Küseler A, Pedersen TK, Herlin T: Intra-articular steroid injection for temporomandibular joint arthritis in juvenile idiopathic arthritis: 
A systematic review on efficacy and safety. Semin Arthritis Rheum 2013; 43(1): 63-70.

73. Niibo P, Pruunsild C, Voog-Oras $\ddot{U}$, Nikopensius T, Jagomägi T, Saag M: Contemporary management of TMJ involvement in JIA patients and its orofacial consequences. EPMA J 2016; 7(1): 12.

74. Beighton P: Hypermobility scoring. $\mathrm{Br} \mathrm{J}$ Rheumatol 1988; 27(2): 163.

75. De Coster PJ, Martens LC, De Paepe: Oral health in prevalent types of Ehlers-Danlos syndromes Oral Pathol Med 2005; 34(5): 298307.

76. De Coster PJ, Van den Berghe LI, Martens $L C$ : Generalized joint hypermobility and temporomandibular disorders: inherited connective tissue disease as a model with maximum expression. J OrofacPain 2005; 19(1): 47-57.

77. Jerjes $W$, Upile T, Shah P, Abbas S, Vincent A, Hopper $C$ : TMJ arthroscopy in patients with Ehlers Danlos syndrome: case series. Oral Surg Oral Med Oral Pathol Oral Radiol Endod 2010; 110(2): 12-20.

78. Létourneau Y, Pérusse R, Buithieu H: Oral Manifestations of Ehlers-Danlos Syndrome. J Can Dent Assoc 2001; 67: 330-334.

79. Scheper MC, de Vries JE, Verbunt J, Engelbert $R H H$ : Chronic pain in hypermobility syndrome and Ehlers-Danlos syndrome (hypermobility type): it is a challenge. J Pain Res 2015; 8: 591-601.

80. Perrini F, Tallents RH, Katzberg RW, Ribeiro $R F$, Kyrkanides S, Moss ME: Generalized joint laxity and temporomandibular disorders. J Orofac Pain 1997; 11(3): 215-221.

81. Berger M, Szkutnik J, Szalewski L, Wójcik D, Bakalczuk M, Ginszt M: Correlation between generalized joint laxity and symptoms of temporomandibular disorders. Pol Merkur Lekarski 2016; 40(238): 248-251.

82. van der Meer HA, Speksnijder CM, Engelbert RHH, Lobbezoo F, Nijhuis-van der Sanden $M W G$, Visscher CM: The Association
Between Headaches and Temporomandibular Disorders is Confounded by Bruxism and Somatic Symptoms. Clin J Pain 2017; 33(9): 835-843.

83. Franco AL, Goncalves DAG, Castanharo SM, Speciali JG, Bigal ME, Camparis $C M$ : Migraine is the most prevalent primary headache in individuals with temporomandibular disorders. J Orofac Pain 2010; 24: 287-292.

84. Speciali JG, Dach F: Temporomandibular dysfunction and headache disorder. Headache 2015; 55(1): 72-83.

85. Headache Classification Committee of the International Headache Society (IHS): The International Classification of Headache Disorders, 3rd edition. Cephalalgia 2013; 33(9): 629-808.

86. Global Burden of Disease Study 2013, Collaborators: Global, regional, and national incidence, prevalence, and years lived with disability for 301 acute and chronic diseases and injuries in 188 countries, 1990-2013: a systematic analysis for the Global Burden of Disease Study 2013. Lancet 2015; 386(9995): 743-800.

87. Emshoff R, Bertram F, Schnabl D, Emshoff I: Association Between Chronic TensionType Headache Coexistenwith Chronic Temporomandibular Disorder Pain and Limitations in Physical and Emotional Functioning: A Case-Control Study. J Oral Facial Pain Headache 2017; 31(1): 55-60.

88. Kostrzewa-Janicka J, Mierzwińska-Nastalska E, Rolski D, Szczyrek P: Occlusal stabilization splint therapy in orofacial pain and tensiontype headache. Adv Exp Med Biol 2013; 788: 181-188.

89. Łazowski J: Podstawy fizykoterapii. AWF. Wrocław 2007.

90. Ferreira MC, Bevilaqua-Grossi D, Dach $F E$, Speciali JG, Gonçalves MC, Chaves $T C$ : Body posture changes in women with migraine with or without temporomandibular 
disorders. Braz J PhysTher 2014; 18(1): 1929.

91. Glaubic-Łątka M, ŁątkaD, Bury W, Pierzchała $K$ : Współczesne poglądy na patofizjologię migreny. Neurologia i Neurochirurgia Polska 2004; 38(4): 307-315.

92. Radat $F$ : Stress and migraine. Revue neurologique 2013; 169(5): 406-412.

93. Gonçalves $M, \quad$ Florencio LL, Chaves T, Speciali JG, Bigal ME, Bevilaqua-Grossi $D$ : Do women with migraine have higher prevalence of temporomandibular disorders? Braz J Phys Ther 2013; 17: 64-68.

94. Goncalves DA, Camparis CM, Speciali $J G$, Castanharo SM, Ujikawa LT, Lipton RB, Bigal $M E$ : Treatment of comorbid migraine and temporomandibular disorders: a factorial, double-blind, randomized, placebo-controlled study. J Orofac Pain 2013; 27(4): 325-335.

95.Berger M, Szalewski L, Bakalczuk $M$, Bakalczuk G, Bakalczuk S, Szkutnik J: Związek między poziomem estrogenu a zaburzeniem skroniowo-żuchwowym: systematyczny przegląd literatury. Prz Menopauzalny 2015; 14(4): 260-270.

96. Bi RY, Meng Z, Zhang P, Wang XD, Ding $Y$, Gan $Y H$ : Estradiol upregulates voltage-gated sodium channel 1.7 in trigeminal ganglion contributing to hyperalgesia of inflamed TMJ. PLoS One 2017; 12(6).
97. Puri J, Hutchins B, Bellinger LL, Kramer PR: Estrogen and inflammation modulate estrogen receptor alpha expression in specific tissues of the temporomandibular joint. Reprod Biol Endocrinol 2009; 31(7): 155.

98. Yasuoka T, Nakashima M, Okuda T, Tatematsu $N$ : Effect of estrogen replacement on temporomandibular joint remodeling in ovariectomized rats. J Oral Maxillofac Surg 2000; 58(2): 189-196.

99. Cheng P, Ma X, Li S: Histologic study of the temporomandibular joints after ovariectomy in rats. Zhonghua Kou Qiang Yi Xue Za Zhi 2000; 35(6): 458-461.

100. Landi N, Lombardi I, Manfredini D, Casarosa E, Biondi K, Gabbanini M, Bosco $M$ : Sexual hormone serum levels and temporomandibular disorders. A preliminary study. Gyneco Endocrinol 2005; 20(2): 99103.

101. Kostrzewa-Janicka J, Pietrzak B, Jurkowski P, Wielgos M, Binkowska M, MierzwińskaNastalska E: Effects of oral contraceptives on the treatment for internal derangements in temporomandibular joints in women. Neuro Endocrinol Lett 2013; 34(6): 566-572.

Zaakceptowano do druku: 21.02.2019 r.

Adres autorów: 41-902 Bytom, Pl. Akademicki 17.

C Zarząd Główny PTS 2019. 